\title{
NILAI-NILAI KEARIFAN LOKAL SEBAGAI PEMBENTUK KARAKTER MASYARAKAT
}

\author{
Sukron Mazid', Danang Prasetyo ${ }^{2}$, dan Farikah ${ }^{3}$ \\ 1,3Universitas Tidar, Magelang \\ 2Sekolah Tinggi Pariwisata Ambarrukmo, Yogyakarta \\ email: sukronmazid@untidar.ac.id,
}

\begin{abstract}
Abstrak: Penelitian ini bertujuan untuk mengetahui kandungan nilai-nilai kearifan lokal yang hidup di masyarakat sehingga mampu menjadi pedoman hidup dalam membentuk karakter masyarakat setempat. Penelitian in merupakan penelitian deskriptif kualitatif. Penelitian dilaksanakan di Magelang Raya yang terdiri atas Kota Magelang dan Kabupaten Magelang dari Mei sampai Agustus 2020. Subjek penelitian ditentukan dengan cara purposive, yakni tokoh-tokoh yang paham tentang kondisi masyarakat dan lingkungan Magelang. Hasil penelitian ini menemukan adanya nilai-nilai kearifan lokal yang mampu membentuk karakter masyarakat Magelang Raya. Kearifan lokal tersebut terdiri atas: (1) unsur sosial masyarakat dengan adanya pondok atau masyarakat pesantren sehingga memberikan corak masyarakat yang religius dan patuh terhadap pemimpinnya, akademi militer yang mampu memberikan teladan karakter yang tanggung jawab, disiplin, patriotik, semangat kebangsaan; (2) unsur keberadaan situs sejarah Candi Borobudur yang membentuk masyarakat memiliki karakter toleransi untuk tetap menjaga keharmonisan dalam keberagaman; (3) unsur budaya atau kesenian musik Gejog Lesung yang sarat akan pesan moral untuk bersama dalam keberagaman dan berbeda dalam kebersamaan; (4) unsur alam dengan adanya Gunung Tidar yang memiliki banyak prasasti dengan tulisan Aksara Jawa yang mengandung falsafah hidup sarat akan pesan moral untuk membentuk karakter jujur, bertanggung jawab, rendah hati, saling tolong-menolong, dan menghindari kekerasan dalam setiap penyelesaian masalah dalam kehidupan.
\end{abstract}

Kata Kunci: nilai-nilai karakter, kearifan lokal, karakter masyarakat

\section{THE VALUES OF LOCAL WISDOM AS A COMMUNITY CHARACTER SHAPER}

Abstract: This study aims to determine the content of local wisdom values that live in the community so that it can become a life guide in shaping the character of the local community. This study is a qualitative descriptive study. The research was conducted from May to August 2020 in Magelang Raya, consists of Magelang City and Magelang Regency. The research subjects were determined by purposive method, namely figures who understand the condition of the community and the environment of Magelang. The results of this research found the values of local wisdom that can create character of the Magelang Raya community. Those local wisdoms are: (1) social elements of society with the existence of a boarding school or pesantren community so that it can make a religious and obedient society to its leaders, military academies that are able to exemplify characters that are responsible, disciplined, patriotic, and have a national spirit; (2) elements of the existence of historical site of the Borobudur Temple which formed a society of tolerance character to maintain harmony in diversity; (3) elements of Gejog Lesung's cultural or musical art, which are full of moral messages to be united in diversity and being different in togetherness; (4) natural elements with the existence of Mount Tidar which has many inscriptions with Javanese script which contain a life philosophy full of moral messages to form honest, responsible, humble characters, help each other, and avoid violence in solving problems in life.

Keywords: the character values, local wisdom, community character

\section{PENDAHULUAN}

Pudarnya batasan interaksi masyarakat global menciptakan suasana borderless world yang merupakan situasi hilangnya batas-batas sosial. Hal ini yang dapat mengancam identitas bangsa dengan berbaur- 
nya budaya dari berbagai negara. Negara yang tidak siap dalam menghadapinya akan mengalami guncangan, bahkan dapat menjadi ancaman keutuhan negara dalam jangka waktu panjang. Masih terbatasnya kesiapan masyarakat di daerah menghadapi era globalisasi membuat minimnya tindakan preventif yang dapat dilakukan untuk mencegah guncangan tersebut (Kurnia, 2018:52). Karakter masyarakat Indonesia yang santun dalam berperilaku, musyawarah mufakat dalam menyelesaikan masalah, local wisdom yang kaya dengan pluralitas, sikap toleransi, semangat gotong-royong telah berubah wujud menjadi hegemoni kelompok-kelompok baru yang saling mengalahkan (Fajarini, 2014: 123).

Salah satu usaha yang dapat dilakukan oleh masyarakat sebagai upaya menghadapi dampak buruk globalisasi dengan tetap berpedoman pada nilai-nilai kearifan lokal sebagai suatu kekuatan. Kearifan lokal dapat berfungsi menjadi penyaring bagi nilai-nilai yang berasal dari luar yang kurang sesuai dengan kultur budaya bangsa (Kurnia, 2018:52). Kearifan lokal merupakan hasil dari pengalaman masyarakat dalam lingkup wilayah tertentu dan belum tentu digunakan oleh masyarakat di wilayah lain. Nilai-nilai tersebut akan melekat sangat kuat pada prinsip hidup masyarakat tertentu, keberadaannya telah melalui perjalanan waktu yang panjang, sepanjang keberadaan masyarakat tersebut (Fajarini, 2014:124). Masyarakat yang merupakan keseluruhan dari entitas sosial dari struktur eksistensi memiliki peranan dalam pencerdasan emosional, dengan kata lain masyarakat merupakan wadah pencerdasan emosional dalam membentuk karakter warga masyarakat pada umumnya (Dewi, 2017: 66).

Seperti halnya pola kehidupan masyarakat Magelang Raya yang terdiri dari
Kota Magelang dan Kabupaten Magelang yang tetap mengedepankan nilai-nilai kearifan lokal dalam aktivitas sehari hari. Seperti penuturan Narwan (wawancara pra research) yang merupakan warga Magelang meyakini bahwa Magelang sebagai pakuning jawa atau puser tanah jowo (titik tengah Pulau Jawa) dengan keberadaan Bukit Tidar mempunyai nilai-nilai kearifan lokal yang menjadikan tonggak kehidupan baik unsur rohani dan ragawi menuju laku urip. Sebagai titik sentral Pulau Jawa mesti menjadi titik awal percontohan dalam membentuk karakter masyarakat. Terlebih lagi karakteristik masyarakat Jawa menurut Suyanto (1990:90) memiliki karakter religius, nondoktriner, toleran, akomodatif, dan optimistik. Selain itu masyarakat Suku Jawa terkenal dengan karakter yang tidak mau melupakan jasa orang lain (orang tua, tokoh masyarakat, ulama, dan sebagainya). Walaupun orang tersebut sudah meninggal, bahkan akan lebih menghormati jika orang tersebut sudah meninggal (Arsadani, 2012: 278).

Penegasan Magelang sebagai wilayah yang memiliki karakteristik yang khas juga disampaikan oleh Yuliatun (wawancara prariset) bahwa potensi alam dan karakter masyarakat yang ada di Magelang Raya memiliki warna tersendiri dengan adanya lokasi pendidikan militer, banyaknya pesantren dari jenjang dasar hingga lansia, ziarah makam sebagai wisata religi, Bukit Tidar yang sarat filosofi hidup, musik tradisional Gejog Lesung, keberadaan Candi Borobuduryang memperkuat semangat gotong-royong masyarakat. Keberadaan makam Syekh Subakir, makam Kiai Sepanjang (pakuhning Tanah Jawi), makam Kiai Semar (Eyang Ismoyo), Tugu Puseran Bumi Tanah Jawa, dan Tugu Tiang Bendera Akademi Militer di Bukit Tidar memperkuat Magelang sebagai wilayah yang memiliki ke- 
unikan tersendiri (Naililhaq, 2020:62). Bukit Tidar yang menjadi ikon Kota Magelang dijadikan nama berbagai lembaga, perhotelan, wisata. Seperti Lembah Tidar, menjadi nama legendaris Akademi Militer TNI AD (Tentara Nasional Indonesia Angkatan Darat), wadah strategis dalam rangka membentuk perwira militer tangguh, tegas dan profesional.

Sebagai tempat yang berada di tengah-tengah Pulau Jawa, sering diadakan kegiatan yang bertajuk Selametan Puser Bumi merawat NKRI (Negara Kesatuan Republik Indonesia) yang digelar oleh masyarakat adat Magelang Raya, seperti yang dilakukan pada Hari Minggu tanggal 24 Maret 2019. Acara ini diberi tajuk Prosesi Umbul Donga Puncak Tidar untuk kedamaian NKRI yang menjadi presentasi bersama masyarakat dan Pemerintah Kota/Kabupaten Magelang dalam upaya menjaga dan merawat rasa nasionalisme. Ritual ini juga menjadi muara harapan supaya Indonesia menjadi lebih baik, ribuan warga menuliskan harapan di secarik kertas yang kemudian ditempel di Gunungan Agung Umbul Donga. Gunungan doa harapan itu kemudian dibakar bersama api dan dibiarkan diterpa angin gunung, mengepulnya asap ke udara sebagai simbol mengantarkan permohonan tadi, dengan harapan supaya dikabulkan oleh Tuhan yang maha esa (Hidayat, 2019).

Polarisasi budaya kehidupan turun temurun yang ditinggalkan nenek moyang menjadikan warga Magelang mempunyai jati diri karakter yang sangat kuat. Terutama dari cara sikap dan perilaku dalam kehidupan masyarakat. Sikap ramah, sopan santun dan saling menghargai sesama menjadi ciri tersendiri bagi masyarakat Magelang. Kehidupan masyarakat yang memiliki karakter dan budaya yang kuat akan semakin memperkuat eksistensi suatu bangsa dan negara (Suyitno, 2012). Hal ini dikuat- kan oleh pendapat dari Yudi Latif (2020) bahwa karakter bukan saja menentukan eksistensi dan kemajuan seseorang, melainkan juga eksistensi dan kemajuan bangsa.

Kearifan lokal, adat istiadat, dan tata nilai yang ada dalam suatu masyarakat merupakan basis dalam mengatur tata perilaku warga masyarakat. Hal ini harus tetap dijaga dan dipertahankan, sehingga kekayaan adat istiatat dan budaya yang ada di kawasan nusantara tetap eksis sampai kapanpun. Dengan demikian, perlu upaya penggalian terhadap apa yang disebut dengan istilah nilai-nilai kearifan lokal (Wariin, 2014: 47). Salah satu yang menarik diteliti seperti kearifan lokal yang hidup di Magelang sebagai mana penulis paparkan pada uraian sebelumnya, terlebih lagi di masyarakat Magelang selalu mengedepankan istilah mematri kebudayaan Jawa, jangan sampai istilahnya Wong Jawa ilang Jawane (Setiawan, 2019b). Hal inilah yang menjadi satu alasan peneliti untuk mengungkap nilai-nilai kearifan lokal yang hidup di masyarakat Magelang Raya. Kearifan lokal yang diteliti berupa kebudayaan, kondisi alam, dan unsur sosial masyarakat yang mampu membentuk karakter masyarakat Magelang.

\section{METODE}

Penelitian ini merupakan penelitian deskriptif kualitatif. Menurut Creswell (2014) penelitian kualitatif adalah serangkaian praktik penafsiran material dari serangkaian representasi, yang mencakup berbagai catatan lapangan, wawancara, percakapan, foto, rekaman, dan catatan pemberi informasi. Metode penelitian dengan metode etnografi untuk menjelaskan hubungan antarkategori yang menurut Endraswara (2015) etnografi merupakan kajian tentang kehidupan dan kebudayaan suatu masyarakat. 
Penelitian dilaksanakan di Magelang Raya yang terdiri dari Kota Magelang dan Kabupaten Magelang dari Bulan Mei sampai dengan Bulan Agustus 2020. Penentuan subjek penelitian dilakukan dengan cara purposive yang disesuaikan dengan tujuan penelitian (Sugiyono, 2013:301). Subjek penelitian ditentukan berdasarkan orang yang dianggap paling tahu tentang informasi yang dibutuhkan. Subjek penelitian dalam tulisan ini adalah K.H. Yusuf Chudori atau yang lebih dikenal dengan Gus Yusuf pengasuh Pesantren Tegal Rejo dan K.H. Labib Asrori atau yang dikenal dengan sapaan Gus Labib pengasuh Pesantren Roudhatut Tullab Tempuran. Yasnanto yang merupakan purnawirawan TNI AD yang tinggal di sekitar Akademi Militer Magelang. Wahyu Utomo sebagai umat Buddha sekaligus tokoh Agama Buddha di Magelang. Bambang Eka Prasetya budayawan Magelang Raya. Yuliatun dan Narwan sebagai masyarakat Magelang.

Pengumpulan data dalam penelitian ini dengan teknik wawancara mendalam, observasi, dan studi dokumen. Peneliti merupakan instrumen utama penelitian. Peneliti sekaligus sebagai perencana yang menetapkan fokus penelitian, memilih informan, sebagai pelaksana pengumpulan data, menafsirkan data, menarik kesimpulan sementara, dan menganalisis data di lapangan yang dialami (Djaelani, 2013: 84). Pemeriksaan keabsahan data penelitian dengan menggunakan metode triangulasi, untuk menguji keabsahan data dilakukan dengan cara triangulasi teknik dan sumber.

\section{HASIL DAN PEMBAHASAN}

Kearifan lokal menyiratkan beberapa konsep, yaitu: (1) kearifan lokal adalah sebuah pengalaman panjang, yang dijadikan sebagai petunjuk perilaku seseorang; (2) kearifan lokal tidak lepas dari lingkungan pemiliknya; dan (3) kearifan lokal itu bersifat dinamis, lentur, terbuka, dan senantiasa menyesuaikan dengan perkembangan zaman. Konsep demikian juga sekaligus memberikan gambaran bahwa kearifan lokal selalu terkait dengan kehidupan manusia yang hidup di lingkungan alam dan sosialnya. Kearifan lokal muncul sebagai penjaga atau filter iklim global yang melanda kehidupan manusia (Wagiran, 2012:330). Sebagaimana kearifan lokal yang hidup di masyarakat Magelang berasal dari interaksi keberadaan manusia dengan kebudayaan, adat istiadat, alam, dan masyarakat sosial di wilayah tersebut. Interaksi tersebut yang menjadikan masyarakat mampu beradaptasi dengan alam dan lingkungannya sehingga kemudian mampu membentuk karakter masyarakat. Adapun nilai-nilai kearifan lokal yang mampu membentuk karakter masyarakat Magelang dapat dipengaruhi oleh keberadaan beberapa hal berikut ini.

\section{Masyarakat Pesantren}

Pendidikan merupakan bagian terpenting dalam menuju masyarakat berkeadaban. Salah satunya adalah pembentukan kecakapan intelektualitas, moralitas dan spiritulitas. Ribuan lembaga pendidikan berbasis pesantren telah berdiri di Magelang, dari tingkat dasar, menengah hingga pesantren untuk lanjut usia (lansia). Keberadaan pesantren memberikan dampak pada kehidupan masyarakat sekitarnya, tentunya dalam pembudayaan naiali religiusitas. Seperti halnya Pondok Pesantren Sepuh Masjid Agung Payaman Magelang yang menjadi santri adalah orang-orang jompo (Machali \& Hidayah, 2014:49) dengan memberikan pembinaan salat, puasa, materi baca Iqra', Alquran, Kitab Al Ibriz mengunakan terjemahan Bahasa Jawa, materi tauhid, materi akhlak. Selain itu ter- 
dapat situs ritus wisata religi makam para Aulia, serta banyak tokoh dan pemuka agama dari Magelang yang dijadikan rujukan atau panutan sebagai penuntun kemaslahatan masyarakat setempat.

Banyaknya tokoh atau sesepuh pesantren yang sangat masyhur, memiliki pengaruh di masyarakat, sehingga sangat dihormati apa yang menjadi dawuh (amanah) dalam menuntun kemaslahatan umat. Beberapa tokoh pesantren yang ditemui oleh peneliti yakni adalah K.H. Yusuf Chudori atau yang lebih dikenal dengan Gus Yusuf pengasuh Pesantren Tegal Rejo dan K.H. Labib Asrori atau yang dikenal dengan sapaan Gus Labib pengasuh Pesantren Raudhatut Thullab Tempuran. Gus Yusuf menyampaikan bahwa santi-santri yang saat ini sedang menimba ilmu diharapkan kelak di dalam kehidupan masyarakat tidak hanya mencerdaskan akal pikiran saja, tetapi membekali diri dengan nilai-nilai akhlak. Apa yang dilakukan guru dan murid di lingkungan pesantren harus memberikan contoh uswah keteladanan. Selain itu, Gus Labib menyampaikan bahwa keberadaan pesantren sangat berpengaruh terhadap kehidupan masyarakat. Terlebih lagi dengan keberadaan sosok ulama yang menjadi panutan masyarakat yang kemudian memunculkan nilai kesetiaan dan kepatuhan. Bahkan saat ulama yang menjadi panutan sudah wafat, makamnya akan terus ramai dikunjungi setiap harinya oleh para santri yang belajar di pondok pesantren yang pernah didirikannya. Hal inilah yang menjadi salah satu alasan sampai saat ini Magelang dikenal dengan banyak makam yang menjadi daya tarik wisata religi. Salah satu makan ulama yang menjadi yang sering dikunjungi dan menjadi bagian dari tujuan wisata adalah wisata pilgrim atau ziarah yang berada di Gunungpring. Wisatawan yang berkunjung pada kawasan wisata tersebut setiap hari selalu ada untuk melakukan wisata ziarah. Wisatawan yang menyempatkan untuk berwisata ziarah dari berbagai daerah itu tentunya banyak yang datang untuk menyambangi wisata yang kaya akan nilai-nilai historis dan budaya (Biroli, Kartono, \& Demartoto, 2015: 63). Wisata religi di Magelang banyak dijumpai makam makam para ulama dan wali Allah yang setiap harinya banyak didatangi peziarah (Bayu, 2020).

Sebagai mana paparan Hermanto, Pasya, Muchtar, et al (2012:11) bahwa kepatuhan kepada pimpinanya didasarkan atas fungsi sosial, psikologis dan religius sehingga mampu meningkatkan kepercayaan warga demi tercapainya keberkahan dan kebahagiaan hidup. Pesantren mampu menjadi pusat percontohan kehidupan berakhlak, berbudaya dan bersyariah dalam kehidupan sehari-hari. Selain itu, pesantren mampu menjadi pusat pengembangan ilmu pengetahuan, terutama ajaran Agama Islam. Dengan memaksimalkan peran serta masyarakat sekitar, pesantren akan memberikan kontribusi besar dalam melahirkan manusia-manusia berilmu, beramal dan berakhlak. Dengan demikian, pesantren menjadi wadah mencetak tokoh-tokoh agama sebagai panutan masyarakat, menjadi pusat pemersatu, dan pendamai bagi masyarakat.

Keberadaan masyarakat pesantren menjadikan Magelang sebagai wilayah yang sangat religious. Dampaknya para warga masyarakat dalam bertindak dan berperilaku berdasarkan kepada ajaran agamannya. Hal tersebut akan tetap menjadi ciri khusus Magelang sebagai tempat menimba ilmu Agama Islam di Indonesia. Terlebih umat Islam di Indonesia adalah mayoritas dan merupakan yang terbesar di dunia. Suku Jawa juga merupakan suku mayoritas di Indonesia. Hal ini menunjukkan bahwa 
Islam dan Jawa merupakan dua hal penting dalam kehidupan berbangsa dan bernegara (Arsadani, 2012:277).

\section{Keberadaan Akademi Militer}

Akademi Militer (Akmil) sebagai lembaga pendidikan pembentukan prajurit perwira pertama tingkat akademik memiliki memiliki peran penting dan strategis dalam penyiapan sumber daya manusia di masa yang akan datang (Riyanto \& Tohirin, 2017). Jiwa patriotik yang ditanamkan serta bela negara menjadikan para perwira mempunyai dedikasi tingggi kepada bangsa dan negara. Nilai-nilai yang ditanamkan adalah disipilin, tangguh, tegas, dan profesional. Karakter inilah yang melekat kepada para perwira sebagai pedoman dalam kehidupan berbangsa dan bernegara. Karakter bangsa adalah kualitas perilaku kolektif kebangsaan yang khas, baik yang tercermin dalam kesadaran, pemahaman, rasa, karsa, dan perilaku berbangsa dan bernegara sebagai hasil olah pikir, olah hati, olah rasa, karsa dan perilaku berbangsa dan bernegara Indonesia yang berdasarkan nilai-nilai Pancasila, UUD 1945, keberagaman dengan prinsip Bhinneka Tunggal Ika, dan komitmen terhadap Negara Kesatuan Republik Indonesia.

Sejak dibentuk dan diresmikannya Akademi Militer (dahulu bernama Akademi Militer Nasional) oleh Soekarnao, Presiden Indonesia yang pertama di Magelang (Firmansyah, 2020) memberikan dampak positif bagi masyarakat sekitar untuk memiliki nasionalisme yang lebih kuat. Masyarakat mampu merasakan manfaat karakter yang menjadi dasar, arah dan pijakan akademi militer yakni dalam bersikap dan berperilaku dengan cara disiplin, tangguh, tegas, professional dan bertanggung jawab. Menurut Yasnanto (purnawirawan TNI AD) yang tinggal di sekitar
Akmil menjelaskan bahwa keberadaan Akmil telah memberikan contoh mengenai disiplin terhadap masyarakat sekitar. Sebagai contoh kebiasaan bangun pagi untuk segera bergegas memulai aktivitas, kemudian pukul 06.00 Akmil akan membunyikan terompet tanda memulai mengibarkan Bendera Merah Putih, dilanjutkan senam pagi dan lari pagi. Bunyi terompet tersebut bahkan sudah dianggap sebagai penggingat masyarakat sekitar untuk segera memulai aktivitas kehidupan, seperti belajar dan bekerja. Selanjutnya terompet akan dibunyikan kembali saat kegiatan menurunkan bendera setiap pukul 18.00, bunyi pada waktu tersebut juga dianggap masyarakat sekitar sebagai penanda untuk kembali ke rumah untuk beritirahat dan menyiapakan bekal untuk beraktivitas di hari berikutnya.

Anggota Akmil yang tinggal di perumahan dinas kompleks Panca Arga, dapat menjadi contoh hidup disiplin, hidup bersih dengan kegiatan peduli lingkungan. Selain itu, setiap tanggal 1 Juli sampai dengan 31 Agustus setiap tahunnya akan dipasang umbul-umbul dan memasang Bendera Merah Putih mulai tanggal 1 Agustus sampai dengan 31 Agustus. Kegiatan ini juga akan diikuti oleh masyarakat sekitar. Adapun pengaruh keberadaan Akmil dalam pembentukan karakter masyarakat yakni membentuk masyarakat setempat untuk hidup disiplin, peduli lingkungan, dan cinta terhadap bangsa negara.

\section{Situs Sejarah Candi Borobudur}

Indonesia merupakan sebuah negara yang memiliki banyak situs sejarah, salah satunya candi yang merupakan peninggalan kerajaan-kerajaan kuno Hindu Buddha. Di Magelang sendiri terdapat lebih dari 15 candi yang masih eksis sampai saat ini, seperti Borobudur, Mendut, Pawon, Ngawen, Asu, Lumbung, Umbul, Retno, Selo- 
griyo, Gunung Wukir, Gunungsari, Losari, Pendem, Brangkal, dan Batur. Candi selalu identik dengan berbagai kisah atau berbagai latar belakang sejarah pembangunanya dan mempunyai makna serta filosofi sendiri dari setiap model bangunan candi. Salah satu warisan dunia yang disahkan oleh UNESCO (United Nations of Educational, Scientific, and Cultural Organization) dan pernah menjadi salah satu keajaiban dunia ialah Candi Borobudur yang terdapat di wilayah Magelang. Borobudur sendiri menjadi sangat terkenal karena merupakan candi besar yang sarat akan nilainilai sejarah, kejuangan dan kebudayaan. Aktivitas pariwisata Candi Borobudur memberikan pengaruh baik terhadap sosial budaya masyarakat (Biantoro \& Ma'arif, 2014: 1047).

Sebagai situs yang sudah mendunia, masyarakat sekitar candi juga berperan dalam merawat nilai-nilai luhur yang hidup sampai saat ini, salah satunya peran sanggar budaya. Pendidikan informal budi pekerti menjadi salah satu mata pelajaran yang diajarkan Omah Sanggar Warisan Budaya Nusantara Borobudur, yang terletak di Dusun Jowahan Desa Wanurejo Borobudur sejak tahun 2018. Selain budi pekerti, di sanggar tersebut juga diberikan mata pelajaran lainnya seperti pendidikan Bahasa Indonesia, Bahas Inggris, Seni Musik, Seni Tari, dan Membatik. Semua materi pelajaran diberikan secara gratis kepada ratusan murid yang bergabung. Secara teknis pelajaran diberikan mulai pukul 15.00 WIB hingga pukul 17.00 WIB setiap hari, kecuali hari Jumat dan Minggu libur. Harapannya keberadaan sanggar tersebut mampu melahirkan penerus bangsa yang bermartabat luhur dan mulia dapat tercapai dengan baik (Yoga, 2019).

Keberadaan candi yang notabene sebagai situs sejarah umat Agama Buddha di antara ratusan pesantren yang berada di wilayah Magelang tidak serta merta menjadi satu hal yang tabu dan bertentangan. Justru keberadaanya mampu menandakan bahwa masyarakat menjunjung tinggi kehidupan toleransi antar umat beragama, karakter ini menjadi ciri khas masyarakat Magelang. Penelitian Kurnia (2018:58) mengupas kerukunan beragama masyarakat Kediri yang mayoritas begarama Islam dapat hidup damai berdampingan meskipun terdapat Gua Maria Lourdes di Desa Poh Sarang, Kecamatan Semen, Kabupaten Kediri. Lebih dari 3000 (tiga ribu) umat Katolik datang ke tempat tersebut untuk berziarah dan berdoa di depan Gua Bunda Maria Lourdes. Meskipun demikian, sampai saat ini kerukunan antarumat beragama di Kediri terjalin sangat erat, sehingga dalam kehidupan sosial masyarakat dapat berjalan lancar dan damai karena memegang prinsip hidup bahwa setiap pemeluk agama mendalami ajaran agama secara intensif, namun dalam hal melestarikan budaya tetap harus dijaga.

Nilai-nilai karakter yang tumbuh dengan keberadaan Candi Borobudur adalah menghormati dan menghargai bersama. Keberadaan lingkungan masyarakat yang toleran seperti ini membentuk warga masyarakat bersifat saling mencintai, menghormati dan menghargai tanpa membedabedakan agama atau golongan. Hal ini diperkuat dengan penuturan Wahyu Utomo sebagai umat Buddha sekaligus tokoh Agama Buddha di Magelang. Keberadaan Candi Borobudur justru mempererat kerukunan antarumat bergama di Magelang Raya, konflik yang mengatasnamakan agama tidak pernah terjadi di tempat ini. Berdasarkan penuturannya, masyarakat Candi Borobudur sudah terbentuk menjadi manusia yang toleran dan senang untuk bergotong royong. 
Keberadaan Borobudur sebagai ikon wisata memiliki andil dalam menyampaikan pesan moral kepada masyarakat. Seperti adanya agenda tahunan Komunitas Adat Brayat Panangkaran di tradisi Ruwat Rawat Borobudur (RRB), terdapat panggung terbuka bagi ratusan seniman kelompok tari tradisional dari berbagai daerah. Di pelataran candi Buddha terbesar di dunia, para seniman menggelar Pradagsina atau berjalan kaki mengitari Candi Borobudur. Sejumlah seniman menggelar pementasan tari kolosal dan pembacaan puisi Kidung Karmawibangga yang menceritakan perjalanan spiritual dalam membangun Candi Borobudur (Hidayat, 2018). Kidung Karmawibangga terdapat pesan moral tentang kebersamaan, kekuatan, dan kerukunan. Kegiatan tersebut dengan cara menari secara bersama meski dengan latar belakang suku, agara, ras, maupun golongan yang berbeda. Tari ini merupakan visualisasi relief Karmawibangga di lantai pertama Candi Borobudur (Hidayat, 2018b). Ruwat rawat adalah prosesi spiritual yang baik untuk dijaga dan diteruskan karena pada prinsipnya melestarikan warisan budaya dapat dilakukan dengan cara menjaga keberlangsungan konsep budaya dari waktu ke waktu. Selain itu, juga terdapat acara Borobudur Marathon 2019 yang merupakan sebuah perlombaanlari diJawa Tengah yang dipersembahkan oleh Pemerintah Provinsi Jawa Tengah. Acara ini berlangsung pada 17 November 2019 dengan tema Synergy \& Harmony yang memiliki arti membangun sinergi bersama dan menemukan keharmonisan dalam keberagaman (Astrid, 2019).

Eksistensinya sebagai ikon pariwisata dunia sampai saat ini karena peran masyarakat yang bersatu padu menjaga dan merasa memiliki situs sejarah tersebut. Hal ini menandakan bahwa candi tersebut bukan hanya dimiliki umat Budha tetapi milik bangsa Indonesia. Keberadaanya berdampak besar kepada masyarakat, baik segi ekonomi, pariwisata, nilai-nilai kearifan lokal, serta menjadi sebuah ikon peradaban bangsa. Hal ini mampu mendatangkan pendapat daerah serta mampu mengangkat ekonomi masyarakat Magelang.

Sekitar candi juga berdampingan banyak tempat ibadah, sampai saat ini mampu hidup berdampingan dengan harmonis dengan tetap menjaga kerukunan, rasa toleransi mampu menjadi budaya kuat di masyarakat, bahkan akan terus tumbuh dan kuat dengan keberagaman yang ada. Masyarakat sudah terbiasa dengan sikap menerima adanya keberagaman sehingga perlu upaya saling mengisi untuk melengkapi dalam hidup berdampingan. Masyarakat sekitar Candi Borobudur sudah terbiasa dengan keberagaman, bahkan mengganggap hal tersebut sebagai hal yang unik menjadi ciri khas di Indonesia dengan pedoman hidup Pancasila. Keberagaman menurut beliau ibarat tuts dalam piano yang memiliki perbedaan bunyi dan tangga nada tetapi memberikan keindahan dalam harmoni bagi pendengarnya.

\section{Musik Gejog Lesung}

Keberadaan Magelang dikelilingi oleh Gunung Merapi, Merbabu, Telomoyo, Andong, Sindoro, Sumbing, dan Menoreh. Kondisi ini menjadikan warga terbiasa berinteraksi dengan alam dengan tercermin dari mata pencaharian warga masyarakat yang mayoritas bertani, berkebun, beternak, serta berdagang. Keadaan geografis yang demikian berpengaruh pada mata pencaharian masyarakatnya, yakni bidang pertanian dengan memanfaatkan penggunaan teknologi sederhana seperti cangkul, waluku, tenaga kerbau untuk mengolah sawah. Selanjutnya petani mengubah gabah (bulir padi) menjadi beras dengan tekno- 
logi nutu (menumbuk). Inilah yang menjadi cikal bakal adanya Musik Gejog Lesung. Alat yang digunakan dalam musik ini berupa lesung (bejana untuk menempatkan padi), yang berpasangan dengan alu juga ada yang menyebut gejog (alat penumbuk), yang dilakukan oleh penumbuk (yang pada umumnya dilakukan oleh perempuan) secara berirama dan menghasilkan bunyi merdu bertalu. Kesenian tradisional musik Gejog Lesung, instrumen utama yang digunakan adalah alu dan lesung. Alu berfungsi sebagai pemukul, sedangkan lesung berfungsi sebagai sumber bunyi. Alu berupa tongkat besar dengan panjang yang bervariasi sedangkan lesung berupa bongkahan kayu besar dengan bentuk menyerupai perahu (Kusumastoto, 2014:49-50). Itulah yang memberi inspirasi alunan musik dari alat penumbuk padi yakni alu dan lesung, yang kemudian dikenal dengan nama musik Gejog Lesung. Musik tradisional ini dijaga kelestariannya oleh Komunitas Musik Tradisi Gejok Lesung Larasati yang memiliki sanggar di Muntilan Kabupaten Magelang (Redaksi Perduki, 2019).

Secara filosofis berdasar keyakinan masyarakat Jawa yang terinspirasi keyakinan Hindu, relasi antara alu dan lesung, kemudian melahirkan musik Gejog Lesung, yang dilakukan leluhur melambangkan keharmonisan. Nama alu terinspirasi dari lingga, sementara lesung terinspirasi dari yoni. Keduanya merupakan pasangan dari laki-laki dan perempuan, dua pribadi berbeda yang serasi untuk menjaga kelangsungan kehidupan manusia. Hal tersebut ditegaskan oleh Bambang Eka Prasetya bahwa gagasan leluhur melahirkan musik Gejog Lesung sangatlah tepat, dengan filosofi melestarikan keharmonisan dalam kehidupan sehari-hari untuk mewujudkan hidup damai, sejahtera, dan bahagia. Aktivitas keseharian masyarakat sebagai petani membutuhkan keuletan serta ketekunan. Aktivitas yang sudah dilakukan oleh leluhur mengajarkan karakter yaitu kesolidan, kerja keras, mandiri, sopan santun, kerja sama, dan gotong-royong untuk peduli terhadap sesama.

Bentuk lesung atau lumpang berbedabeda tergantung kreatifitas pembuat, demikian pula bentuk alunya. Keunikan dari permainan musik ini ialah para pemain diberi kebebasan untuk berimpropisasi seluas-luasnya tergantung dari kemahiran mengatur keserasian dengan pasangan pemain maupun pasangan lainnya. Dalam permainan musik ini ada istilah 'bersama dalam keberagaman' dan 'berbeda dalam kebersamaan' (Aesijah, 2007:2).

Musik dalam hubungannya dengan masyarakat dapat meciptakan hubungan yang solid antara satu orang dengan orang yang lain. Keberadaan musik sebagai pemersatu masyarakat dinilai mampu menyatukan perasaan satu sama lain. Gejog Lesung sebagai pemersatu masyarakat sudah ada sejak jaman dahulu (Kusumastoto, 2014:47). Gejog Lesung sebagai sarana edukasi ditinjau dari sajian yang ditampilkan berupa lagu dan dolanan yang di dalamnya terkandung pesan moral yang mengarah kepada kebaikan tentang nilai luhur kehidupan (Kusumastoto, 2014:43) yang merupakan bagian dari budaya Jawa dengan tujuan supaya nyanyian tersebut tetap hidup dan tidak tergeser modernisasi budaya asing. Masyarakat Magelang selalu menampilkan kesenian Gejog Lesung pada acara-acara kesenian, baik skala kecil maupun besar. Seperti yang dilakukan para ibu sekitar kawasan Candi Borobudur yang dengan suka cita memainkan musik dari lesung secara beramai ramai, sebagian dari mereka bernyanyi dan menari sesuai irama musik tradisional tersebut untuk menyambut para peserta Borobudur Marathon 2019 
(Nursalikah, 2019).

\section{Wisata Budaya Gunung Tidar}

Keberadaan Gunung Tidar bagi sebagian masyarakat Magelang lebih populer dikenal dengan nama Bukit Tidar. Menurut Bambang Eka Prasetya, sudah ada beberapa orang yang bertanya tentang penyebutan bukit dengan nama gunung, namun hal ini bukanlah masalah esensialnya, selama ini telah terbiasa menyebut bukit tersebut dengan nama Gunung Tidar, walaupun tetap boleh disebut Bukit Tidar. Bukit ini salah satu pakuning Jawa atau terletak di tengah-tengah Kota Magelang dan di tengah-tengah Pulau Jawa. Ada beberapa makam tokoh yang dihormati masyarakat di Bukit Tidar seperti Makam Syekh Subakir berada di area yang letaknya pertengahan dari puncak Bukit Tidar, kemudian menapaki tangga sekitar 100 berikutnya terdapat makam Kyai Sepanjang. Saat di puncak Bukit Tidar terdapat makam Pangeran Purboyo dan makam Eyang Ismoyo Jati (Setiawan, 2019). Tempat ini dikenal dengan lokasi wisata budaya dengan nuansa kejawen, selama ini dikenal dengan sebutan Wisata Budaya Gunung Tidar.

Banyak pesan moral yang dapat didapatkan dengan berkunjung ke tempat ini. Seperti keberadaan gong besar yang dikenal dengan Gong Perdamaian di kaki bukit tersebut. Selanjutnya di gerbang masuk loka wisata Gunung Tidar, pengunjung akan disuguhkan alunan musik tradisional Gejog Lesung. Pemain musik tersebut merupakan warga sekitar Magelang Raya yang tergabung dalam Komunitas Musik Tradisi Gejok Lesung Larasati yang memiliki sanggar di Muntilan Kabupaten Magelang.

Di tengah lapangan puncak bukit tidar ada sebuah prasasti setinggi dua meter yang memiliki empat bidang. Pada bi- dang pertama terdapat gambar Garuda Pancasila, dan di ketiga bidang yang lain tertulis Aksara Jawa Sa Sa Sa. Prasasti itu dikenal dengan nama Prasasti Sapa Salah Seleh (barang siapa salah maka akan ketahuan). Aksara ini dapat dimaknai sebagai pedoman pembentuk karakter bahwa kalimat yang ada di prasasti tersebut mengindikasikan sifat serta sikap jujur yang menjadi bagian integritas dalam sebuah kehidupan.

Kemudian tempat tertinggi di Bukit Tidar, terdapat pesanggrahan Ki Ismaya Jati. Bangunan berbetuk kerucut bercat kecemasan terdapat aksara dekoratif yang melingkari pangkal bangunan berbentuk kerucut yang berlandaskan fondasi segi empat. Empat gugus Aksara Jawa yang melingkari pangkal bangunan berbentuk kerucut ini, dapat dibaca dengan dua cara melangkah. Langkah pertama dengan berputar ke arah kiri, berlawanan dengan arah gerak jarum jam. Ketika melangkah ke arah kiri empat gugus Aksara Jawa itu, dapat membaca tulisan ha na ca ra ka, da ta sa wa la, pa dha ja ya nya, ma ga ba tha nga. Arti aksara hanacaraka itu menceritakan ada utusan, datasawala berarti mereka berselisih paham, padhajayanya berarti mereka beradu kesaktian, dan magabathanga berarti mereka sama- sama mati. Pemaknaan itulah yang terekam dalam ingatan warga masyarakat Jawa pada umumnya. Tersirat makna bahwa manusia yang tidak memiliki pendirian dan mandiri, kemudian segala urusan atau masalah diselesaikan melalui perantara, kemudian berujung terjadi perselisihan, masing-masing pihak merasa benar, selalu beradu pendapat, yang berkembang menjadi adu kekerasan fisik, akhirnya samasama merugi, yang didapat hanya babak belur, dan yang paling mengenaskan akan saling membunuh. Hal itu harus dihindari, maka pesan moral berikutnya dengan meng- 
ganti sebaliknya.

Cara yang kedua untuk memahami makna Aksara Jawa dekoratif itu membaca seraya melangkah ke arah kanan, sesuai dengan arah gerak jarum jam. Aksara tersebut dibaca dari belakang ke depan yakni nga tha ba ga ma, nya ya ja dha pa, la wa sa ta da, ka ra ca na ha. Makna Caraka Walik itulah yang mestinya terekam kuat di laku urip manusia. Makna secara rinci yakni nga tha ba ga ma berarti tiada kematian sehingga saling menghidupi. Kemudian aksara nya ya ja dha pa berarti tanpa adu kesaktian dan kekerasan dengan berusaha saling tolong menolong sesama manusia. Selanjutnya aksara la wa sa ta da berarti selalu berusaha bersikap rendah hati dan saling menyadari bahwa sebagai manusia memiliki banyak kekurangan sehingga perlu saling melengkapi. Terakhir aksara ka ra ca na ha berarti menyelesaikan berbagai masalah dan berani mengambil keputusan secara mandiri. Menurut Naililhaq (2020:62) keberadaan aksara tersebut dapat dikenal dengan Mite Gunung Tidar yang merupakan sastra lisan dan perlu dijaga kelestariannya. Mite atau cerita rakyat dari nenek moyang mengandung nilai-nilai kearifan lokal yang dapat dijadikan pedoman hidup secara turun temurun. Oleh karena itu, kearifan yang terdapat dalam sastra lisan senantiasa dijaga oleh masyarakat supaya tidak hilang ditelan zaman. Ini dapat dimaknai bahwa prasasti yang ada di Bukit Tidar menginspirasi dan menjadi landasan hidup dalam kehidupan bermasyarakat warga Magelang untuk selalu jujur, bertanggung jawab, saling tolong menolong, rendah hati, tidak membiasakan menyelesaikan masalah dengan kekerasan.

Keberadaan pesantren, situs candi, akademi militer, Gunung Tidar yang memberikan pengaruh terhadap pembentukan karakter masyarakat menegaskan bahwa kearifan lokal selalau ada dalam setiap jengkal kehidupan masyarakat. Kearifan tersebut harus tercermin dari cara berpikir, bersikap, dan berperilaku (Wagiran, 2012: 321). Perlu peran masyarakat untuk merawat kearifan lokal untuk tetap hidup secara harmonis dengan lingkungan alam dan masyarakat setempat. Langkah yang paling bijak dengan cara menjadikan kearifan lokal sebagai pandangan hidup sehari hari, pengetahuan norma kehidupan, keyakinan kebenaran, pemahaman untuk memaknai pesan moral yang terkandung, wawasan, menjadikannya kebiasaan, etika masyarakat lokal untuk dilaksanakan. Meskipun bersifat tradisional namun keberadaan kearifan lokal merupakan hasil hubungan timbal balik antara masyarakat dan lingkungan sekitarnya, sehingga sangat cocok untuk dijadikan pedoman hidup (Sardi, Sarwoprasodjo, Lubis, et al, 2019:137). Kearifan lokal hanya akan abadi apabila terimplementasikan dalam kehidupan konkret sehari-hari untuk merespons dan menjawab arus zaman yang telah berubah (Fajarini, 2014:129).

\section{SIMPULAN}

Berdasarkan hasil penelitian dan pembahasan, dapat disimpulkan bahwa terdapat beberapa nilai kearifan lokal yang sudah terpatri dalam kehidupan masyarakat sehingga mampu membentuk karakter masyarakat setempat. Kearifan lokal yang berasal dari kekayaan alam, situs sejarah, lingkungan masyarakat, budaya yang mengandung pesan moral dalam membentuk karakter masyarakat. Keberadaan masyarakat pesantren dari jenjang dasar hingga lansia membentuk mayarakat yang religius, patuh terhadap pemimpinnya. Keberadaan akademi militer membentuk masyarakat sekitarnya menjadi masyarakat yang disiplin yang memiliki semangat kebangsaan yang 
kuat. Keberadaan situs sejarah seperti Candi Borobudur yang berada di lingkungan masyarakat mayoritas muslim akan tetap memberikan nuansa religiusitas dengan semangat toleransi dan gotong-royong. Faktor geografis dengan keberadaan Bukit Tidar sebagai titik tengah Pulau Jawa memiliki kesenian musik Gejog Lesung sebagai simbol masyarakat yang kerja keras dalam mengelola hasil alamnya, bersama dalam keberagaman, dan berbeda dalam kebersamaan. Selain itu, banyaknya prasasti dengan tulisan yang mengandung pesan-pesan moral dapat menjadi pedoman masyarakat untuk berlaku jujur, bertanggung jawab, rendah hati, saling tolong menolong, dan menghindari kekerasan dalam setiap penyelesaian masalah dalam kehidupan.

\section{UCAPAN TERIMA KASIH}

Penulis menyampaikan ucapan terima kasih kepada para narasumber yakni K.H. Yusuf Chudori pengasuh Pesantren Tegal Rejo, K.H. Labib Asrori pengasuh Pesantren Roudhatut Thullab Tempuran, Yasnanto yang merupakan purnawirawan TNI AD yang tinggal di sekitar Akademi Militer Magelang, Wahyu Utomo sebagai umat Buddha sekaligus tokoh Agama Buddha di Magelang, Bambang Eka Prasetya budayawan Magelang Raya, Yuliatun dan Narwan sebagai masyarakat Magelang yang berkenan memberikan informasi untuk mencapai tujuan penelitian yang diharapkan.

\section{DAFTAR PUSTAKA}

Aesijah, S. (2007). Makna simbolik dan ekspresi musik kotekan. Harmonia: Journal of Art Research and Education, 8(3), 1-6. DOI: https://doi.org/10.15294/harmonia.v8i3.774.
Arsadani, E. (2012). Islam dan kearifan budaya lokal: Studi terhadap tradisi penghormatan arwah leluhur masyarakat Jawa. Jurnal ESENSIA: Jurnal Ilmu-Ilmu Ushuluddin, 13(2), 277-288. DOI: https:/ / doi.org/10.14421/esens ia.v13i2.742.

Astrid. (2019). Masyarakat sambut Borobudur Marathon dengan kesenian tradisional. Retrieved July, 252020 from https://www.indozone.id/travel/kJsAd4 /masyarakat-sambut-borobudur-marathon-dengan-kesenian-tradisional/read-all.

Bayu. (2020). Daftar empat makam ulama besar di Magelang yang ramai peziarah. Retrieved July, 252020 from https:// borobudurnews.com/daftar-empat-makam-ulama-besar-di-magelang yang-ramai-peziarah/.

Biantoro, R., \& Ma'rif, S. (2014). Pengaruh pariwisata terhadap karakteristik sosial ekonomi masyarakat pada kawasan objek wisata candi Borobudur Kabupaten Magelang. Teknik PWK (Perencanaan Wilayah Kota), 3 (4), 1038-1047. Retrieved from https://ejournal3.undip.ac.id/index.php/pw k/article/view/6856.

Biroli, A, Kartono, D.T., \& Demartoto, A. (2015). Rasionalitas wisatawan wisata pilgrim (studi fenomenologi terhadap wisatawan di kawasan wisata pilgrim desa Gunungpring, Kecamatan Muntilan, Kabupaten Magelang). Jurnal Analisa Sosiologi, Oktober 2015, 4 (2): 60-74. DOI: https://doi.org/10.20961/jas.v4i2.17440.

Creswell, J.W. (2014). Research design: Qualitative, quantitative and mixed methods approaches: Fourth edition. Thousand Oaks, CA: Sage Publications. 
Dewi, D.A. (2017). Membangun karakter kebangsaan generasi muda bangsa melalui integrasi pendidikan formal, informal dan nonformal. CIVICS: Jurnal Pendidikan Pancasila dan Kewarganegaraan, 2(1), 56-67. DOI: https://doi.org/10.36805/civics.v2i1.267.

Djaelani, A.R. (2013). Teknik pengumpulan data dalam penelitian kualitatif. Majalah Ilmiah Pawiyatan, 20(1), 82-92.

Endraswara, S. (2015). Etnologi Jawa. Yogyakarta: Center of Academic Publishing Services.

Fajarini, U. (2014). Peranan kearifan lokal dalam pendidikan karakter. Sosio Didaktika: Social Science Education Journal, 1(2), 123-130. DOI: 10.15408/sd.v1i2.1225.

Firmansyah, Z. (2020). Foto: Drama kolosal sejarah berdirinya akademi militer. Retrieved May, 12020 from http://beritamagelang.id/gallery-photo/drama-kolosal-sejarah-berdirinyaakademi-militer.

Hermanto, Pasya, G.K., Muchtar, S.A., \& Sumaatmadja, N. (2012). Filosofi hidup sebagai basis kearifan lokal (studi pada kesatuan masyarakat adat kasepuhan Banten Kidul). Jurnal Geografi Gea, 12(1), 1-14. DOI: https://doi.org/10.17509/gea.v12i1.2593.

Hidayat, W. (2018). Ruwat rawat borobudur dimeriahkan ratusan pentas penari di jalanan. Retrieved July 252020 from http:/ / beritamagelang.id/ruwat-rawat-borobudur-2018-meriah-ratusanpenari-pentas-dijalanan.

Hidayat, W. (2018b). Ribuan wisatawan candi Borobudur dihibur pagelaran seni kolosal Kidung Karmawibhangga. Retrieved July, 252020 from http://beritamagelang.id/ribuan-wisatawan-can- di-borobudur-pagelaran-dihibur-pagelaran-seni-kolosal.

Hidayat, W. (2019). Ribuan warga ikuti prosesi Umbul Donga di Gunung Tidar. Retrieved May, 12020 from http://beritamagelang.id/ribuan-warga-gelar-prosesi-umbul-donga-di-gunungtidar.

Kurnia, I. (2018). Mengungkap nilai- nilai kearifan lokal Kediri sebagai upaya pelestarian budaya bangsa Indonesia. Jurnal PGSD: Jurnal Ilmiah Pendidikan Guru Sekolah Dasar, 11(1), 51-63. DOI: https:/ /doi.org/10.33369/pgsd. 11.1.51-63.

Kusumastoto, P. (2014). Fungsi dan bentuk penyajian musik Gejog Lesung di Candirejo Bokoharjo Prambanan Sleman Yogyakarta. Skripsi. Yogyakarta: Fakultas Bahasa dan Seni Universitas Negeri Yogyakarta.

Latif, Y. (2020). Wawasan Pancasila bintang penuntun untuk pembudayaan edisi komprehensif. Jakarta: Mizan.

Machali, I., \& Hidayah, N.S. (2014). Pendidikan Agama Islam pada santri lanjut usia di Pondok Pesantren Sepuh Masjid Agung Payaman Magelang. An-Nur: Jurnal Studi Islam, 6(1), 41-59. Retrieved from http://jurnalannur.stiq.ac.id/index.php/AnNur/art...

Naililhaq, F.N. 2020. Kearifan lokal bertajuk religi dalam mite gunung Tidar: Kajian antropologi sastra. Jurnal Pendidikan Bahasa dan Sastra, 20(1), 61-70. DOI: https:/ / doi.org/10.17509/bs_jp bsp.v20i1.25972.

Nursalikah, A. (2019). Pelari Borobudur Marathon 2019 disambut kesenian tradisional. Retrieved July, 252020 from https://www.republika.co.id/berita/nasiona 
1/daerah/19/11/17/q13fxl3 66-pelari-borobudur-marathon- 2019-disambut-kesenian- tradisional.

Redaksi Perduki. (2019). Memainkan gejog lesung bersama Larasati Magelang. Retrieved July, 252020 from http://perduki.org/2019/04/10/memainkan-gejog-lesung-bersama-larasatimagelang/).

Riyanto, S., \& Tohirin, M. (2017). Pendidikan taruna/taruni Akademi Militer dalam membentuk karakter bangsa melalui spiritualitas keagamaan. Jurnal Tarbiyatuna, 8 (1), 44-55. Retrieved from http://journal.ummgl.ac.id/index.php/tarbiyatuna/article/view /1757.

Sardi, Sarwoprasodjo, S., Lubis, D.P., \& Suharjito, D. (2019). Kearifan lokal: Sebuah analisis sosiologi komunikasi di Manggarai Barat (Local Wisdom: a Sociology of Communication Analysis in West Manggarai). Sodality: Jurnal Sosiologi Pedesaan, 7(2), 136-142. DOI: 10.22500/sodality.v7i2.25453.

Setiawan, B. (2019). 3 pilihan wisata di Bukit Tidar Magelang. Retrieved July, 252020 from https://travel.tempo.co/read/11890 63/3-pilihan-wisata-di-bukittidar- magelang/full\&view $=$ ok.

Setiawan, B. (2019b). Selametan Puser Bumi: Wong Jawa Ojo Ilang Jawane. Retrieved July, 252020 from https://travel.tempo.co/read/11887 85/selametanpuser-bumi-wong-jowo-ojo-ilang-jawane $/$ full\&view $=$ ok.

Subianto, J. (2013). Peran keluarga, sekolah, dan masyarakat dalam pembentukan karakter berkualitas. Edukasia: Jurnal Penelitian Pendidikan Islam, 8 (2), 331354.DOI: http:/ / dx.doi.org/10.21043/edukasia.v8i2.757.
Sugiyono. (2013). Metode penelitian pendidian:Pendekatan kuantitatif, kualitatif, dan RED. Bandung: Penerbit Alfabeta.

Suyanto. (1990). Pandangan hidup Jawa. Semarang: Penerbit Dahana Prize.

Suyitno, I. (2012). Pengembangan pendidikan karakter dan budaya bangsa berwawasan kearifan lokal. Jurnal Pendidikan Karakter, 2(1), 1-13. DOI:https://doi.org/10.21831/jpk.v0i1.1 307.

Wagiran. (2012). Pengembangan karakter berbasis kearifan lokal Hamemayu Hayuning Bawana (Identifikasi nilainilai karakter berbasis budaya). Jurnal Pendidikan Karakter, 2(3), 329-339. DOI: https://doi.org/10.21831/jpk.v 0i3.1249.

Wariin, I. (2014). Nilai-nilai kearifan lokal (local wisdom) tradisi memitu pada masyarakat Cirebon (Studi masyarakat Desa Setupatok Kecamatan Mundu). Edunomic Jurnal Pendidikan Ekonomi, 2(1), 47-56. Retriefed from https://www.fkip-unswagati.ac.id/ejournal/index.php/edunomic/articl e/view/36/34.

Yoga,C. (2019). Pendidikan budi pekerti omah sanggar warisan budaya nusantara Borobudur. Retrieved July, 252020 from http:/ / beritamagelang.id/ pendidika n-budi-pekerti-omah-sanggar-warisan-budaya-nusantara- borobudur. 